\title{
Quality of services through e-governance: The Indian Experience
}

\author{
Vinod Kumar, \\ (Assistant Professor (Guest Faculty), Department of evening studies, Panjab University, Chandigarh (India)
}

\begin{abstract}
The Citizen-Centric governance is aimed to meet the felt needs of the people, solve their common problems and redress grievances at their doorstep. E-DISHA (Ekal Seva Kendra: Common Service Centres) initiative of Haryana Government is an effort towards creating a Citizen Services Network, a way to take the governance to the citizens and hence make it available even at the grass-root level. This is aimed to provide citizens access to information about government services and processes, knowledge about the local best practices and contents, and delivery of government services at their doorstep. This paper gives an overview of eDISHA initiative of Haryana government.
\end{abstract}

\section{INTRODUCTION}

In a democratic polity, citizens expect speedy and transparent delivery of public services. In this direction, E-Governance comes as an excellent tool for government to respond to the increasing demand from citizens and to accelerate the pace of development ${ }^{1}$. The Information revolution has changed the world like never before. E-Governance has been acknowledged as a tool for promoting efficiency and effectiveness in government and it can play a huge role in public service delivery. E-Governance has also been defined as the "one stop nonstop" operation of public services. Many developing countries are now realizing the need for eGovernance in order to provide customer-focused, cost effective, and easy to use services for citizens and businesses and to improve the internal workings of government. For this, the government of India and the World Bank on May 10, 2011 signed an agreement of us $\$ 150$ million for "e-delivery of public services development policy loan", 2 under the national e-governance plan (NeGP), a flagship e-governance initiative of the government of India aimed at transforming the service delivery system across the country. The vision of the agreement is to make all government services accessible to the common man in his locality, through common service delivery outlets and ensure efficiency, transparency and reliability of such services at affordable costs to realize the basic needs of the common man, NeGP has identified various key components including common core and support infrastructure and several mission mode projects to be implemented at the central, state and local government levels. This paper is thus highlighted the importance of ICT and their contribution to excellence in services. The key issue within the context of services is service delivery, which is the process of making available the use of services for consumers, in an efficient and convenient manner. The government can provide value by providing service delivery which consists of the location timing and manner by which it is distributed.

\section{E-governance in Indian states}

Various states governments have also taken various innovative steps to promote e-governance and drawn up a roadmap for IT implementation. Various projects are being implemented for improving the service delivery to the citizens through e-governance. One such step is the establishment of service centers. These Service Centers are established in public-private partnership mode and centers are providing multiple online services, such as, payments of taxes, land record, driving license, registration of birth, deaths and marriages, payments of water, telephone and electricity bills, issue passport, bus passes and old age cards etc. Through online services citizens have benefited from reduce delay, multiple solution at one counter. As a result, transparency, accountability and efficiency in administration have been increased ${ }^{3}$. E-governance initiatives select states have been mentioned as under:

\footnotetext{
${ }^{1}$ Tejinder Sharma, (2002), "e-governance: Process Re-engineering Approach" The Indian Journal of Public Administtraton, Vol XLVIII, No.4, October-December. P-607

${ }^{2}$ http://mit.gov.in/sites/upload_files/dit/files/WBText_1352011.pdf
}

${ }^{3}$ Anil Monga, Akshat Mehta and Kuldeep Singh (2007), "E-Governance and Quality of Service: The Indian Experience", Management in Government, October-December, pp. 37-50. 


\section{E - Sewa}

The Andhra Pradesh government has launched a twin project for the two cities Hyderabad and Secandrabad, in Andhra Pradesh. Later on in august of 2001 the project was re-launched as an improved version and christened as e-Sewa, The aim here is to provide a one stop, under a single-roof contact point for availing a wide spectrum of services from a number of different departments. E-Sewa at present offers a host of services to citizens in a seamless fashion such as payment of public utility bills, like water, electricity, telephone, submission of passport application, booking tickets, etc. Its on-line manifestation, the www.esewaonline.com, offers information on issues of interest and also provides downloadable forms and external links. However, what makes it unique is the offline manifestation of e-Sewa; it has also established around $44 \mathrm{e}$-Sewa centres spread over the twin cities and Ranga Reddy district. These centres service nearly 12 million people in the area. ${ }^{4}$

\section{City civic centre (e- city)}

This project was started at Ahmadabad Municipal Corporation (AMC) to facilitate better performance of the delivery of municipal services. For this AMC has establish six city civic centres which are located in five zones of city and also created forty-three ward civic offices all these interconnected via internet connectivity. As the city civic centre is on the network and connected to the main server which in turns is connected through the global internet protocol, the citizens can track the status of their application later on through the corporation web site. For doing so, a unique registration number is allotted to every applicant, which can be later used to track the status. Citizens can take information through websites www.egovamc.com by click of a button, citizen can also avail various services at single window.

\section{Bhoomi}

The government of karnataka, embarked upon a project "Bhoomi" in 2002 designed by national informatics canter, bangalore, under which the entire land records in karnataka were to be computerised and made open to public. In all 20 million records of land ownership of 6.7 million farmers were digitalized through 177 government-owned kiosks in the state. The Bhoomi project changed the entire system by converting the data into digital format. The information made available to the people under a simple and user friendly procedure which is convenient and quick. In 177 talukas touch-screen kiosks (Bhoomi Centres) were set-up from where farmers could get the revenue documents within a short time by paying rs 15 as user fee. ${ }^{5}$ This has been a success as it has brought about transparency and speed in government working leading to reduction in corruption and delay.

\section{FRIENDS}

FRIENDS or "Fast, Reliable, Instant and Efficient network for disbursement of services" was started in 2000 in Thiruvananthpuram by the kerala state department of information technology with the help of local bodies. The friends centre, or Janasevana kendram, is a one-stop integrated citizen service centre of the government of kerala. The centre functions as a single counter to remit utility bill payments, submit applications, seek information on government programmes and schemes, and provide access to other specialty services. Later on FRIENDS was launched in the remaining 13 district headquarters in 2001. The centre works from $9 \mathrm{am}$ to $7 \mathrm{pm}$ in two shifts from $9 \mathrm{am}$ to $2 \mathrm{pm}$ and from $2 \mathrm{pm}$ to $7 \mathrm{pm}$ on all days including Sundays without lunch breaks. The centre is closed on every second Saturday and on public holidays. ${ }^{6}$

\section{Gyandoot}

Gyandoot initiated in January 2000 by a committed group of civil servants in consultation with various gram panchayats in the Dhar district of Madhya Pradesh. Gyandoot is a low cost, self-sustainable, and community-owned rural intranet system (Soochnalaya) that caters to the specific needs of village communities in the district. Gyandoot aims to create a cost-effective, replicable, economically self-reliant and financially viable model for taking the benefits of Information and Communication Technology (ICT) to the rural masses. 35 such centres have been established since January 2000 and are managed by rural youth selected and trained from amongst the unemployed educated youth of the village. ${ }^{7}$

\footnotetext{
${ }^{4}$ Vivek Gupta and Prashanth (2004) "The E-seva Project: Providing G2C Services in Andhra Pradesh (India)", e-government Concepts and Cases, the ICFAI University Press., Hyderabad, pp. 164-183.

${ }^{5}$ C.S.R. Prabhu (2004) "E-governance Concepts and Case Studies", Prentice Hall of India, New Delhi, pp.116126.

${ }^{6} \mathrm{http}: / /$ www.apdip.net

${ }^{7}$ S.N sangita and Bikash Chander Dash, (2008), "The Indian Journal of Public Administtraton, Vol LIV, No.1, Janurary-March,pp.141-159
} 


\section{E-suvidha}

The department of information technology and electronics, government of Uttar Pradesh has decided to create and develop an electronic bridge between the common citizen and the government departments and constituted the state smart city project unit (e-suvidha), E-suvidha has proposed to implement an information technology enabled public utility interface across the state of Uttar Pradesh and to begin with initially started on pilot basis in the city of Lucknow in august, 2006. E-suvidha provides a one stop interface to citizen to interact with government departments. At present there are 31 e-suvidha centres in Lucknow operate from 8 am to 8 pm on all working days including Sundays and holidays. Citizens can avail any service from any of the e-suvidha service centres across any counter without any jurisdictional limit. All e-suvidha service centres accept all forms of payments including credit cards. ${ }^{8}$

\section{LOKMITRA}

The Government of Himachal Pradesh is committed to provide the benefits of Information Technology to general public especially living in distant rural areas of the State. The Common Service Centre (CSC) named "LOKMITRA" scheme is one such step of the State Government in that direction. LOKMITRA, a G2C project, provides an interface for the citizens to interact with various government functionaries and solicits the active and direct contribution of citizens in the process of governance. The project is based in Hamirpur district consists of two Pentium-III-based Servers (Under Windows NT), with 4 Pentium-III-based Client systems and a Router, set up in a LAN using HUB in a separate room at the Deputy Commissioner office, Hamirpur, named as LokMitra Soochnalaya. A total of 25 panchayats have been identified for setting up Citizen Information Centres. The project will be extended to cover all the districts of Himachal. The project was initiated by the Department of Information Technology, Government of Himachal Pradesh. The software was developed by National Informatics Centres (NIC), Himachal Pradesh State Unit Shimla. ${ }^{9}$

\section{SETU}

Harnessing the benefits of Information Technology for effective and transparent functioning of the administration is one of the core focus areas of the IT policy of the Government of Maharashtra. To ensure time bound service delivery to citizens, the government has initiated the program to set up citizen facilitation centres known as Integrated Citizen Facilitation Centres (SETU). It acts as a credible link between the citizens and the government. The SETU is work on these very basic needs of the citizens and reorienting administrative processes accordingly. The aim is to lay the foundation for e-governance, create visible impact of the intention of the Government in this direction, and facilitate the interaction of the citizens with the Government to make it more transparent, pleasant and satisfying ${ }^{10}$.

\section{E-Disha Centres in Haryana: A study}

Haryana, the "Karambhoomi" emerged as a separate state in the federal galaxy of the Indian Republic on November 1, 1966, with just 44212-sq.km area, have 21 Districts in the state, further it is divided 67 Tehsils, and 6759 villages. The government of Haryana has given a special emphasis on implementing Information Technology (IT) policy with an aim that is all citizens should access government and private sector services from their own villages and towns. ${ }^{11}$ The Master Service Agreement (MSA) for the implementation of the common services centers (CSC) "E-DISHA" scheme in Haryana was signed on April 17 ${ }^{\text {th }} 2007$, between Financial Commissioner (Information Technology) on the behalf of Government of Haryana and the Managing Director of Hartron.

To achieve this objective, The Government of Haryana has implemented the common services centres scheme in the state. As per the IT policy of State, there has been established 1159 rural "E-DISHA" CSC throughout the state as single window services delivery point for government, business and citizen services. Another 55 CSCs, in urban areas and 49 show case CSCs at District Headquarter. At present, the following services have been integrated and offered from "E-DISHA EKAL SEVA KENDERA" centres for the people: Forms and Procedures; Birth and Death Certificate of Urban Areas; House Tax Collection, Social Welfare Schemes Application acceptance; Issue of Caste and Residence Certificate; Passport Application collection; Arms Licence; Driving License; Vehicle Registration Certificate services. ${ }^{12}$

\footnotetext{
${ }^{8}$ http://www.esuvidha.goup.in/

${ }^{9}$ Anil Monga, Akshat Mehta, Kuldeep Singh, (2007), "e-governance and quality of Services: The Indian Experience, October-December, pp.37-52

${ }^{10} \mathrm{http}: / / w w w . m a h a r a s h t r a . g o v . i n$

${ }^{11}$ www.hartron.org

${ }^{12}$ www.haryana.gov.in
} 


\section{Research Methodology}

The study has used both primary and secondary data. Secondary data have been collected from the documents of Government of Haryana, various reports by commissions and committees submitted from time to time, websites of government at the union as well as state levels and various national and international agencies having interest on e-governance.

Secondary data has been collected from the citizens, for this a survey was conduct and citizen availing the facility through e-disha were asked to express their opinion regarding the quality of services and their expectations on the time; accessibility; reliability; responsiveness; physical facilities. Schedule was administered to the citizens to examine the level of their satisfaction towards the services being provided by the e-disha centers. The Government has divided the area in the state into four divisions for the purpose of establishment of CSC in Haryana. Out of these four divisions, two divisions would be selected and further from each division one district selected randomly. From each district a sample of 100 citizens from Rewari and 100 citizens from Panchkula CSC was collected.

\section{Comparative Analysis of Results}

Haryana government has established one e-disha canter at Panchkula mini-secretariat and one e-disha canter at Rewari mini-secretariat. These canters are engaged in providing various services to the citizens of concerned area.

\section{Single Window System}

To check the satisfaction of citizen regarding the single window system an attempt was made. $98 \%$ of respondent were satisfied with single window system. The citizens were happy with this initiative of Haryana government. $70 \%$ respondents have suggested that some more services should be made available at e-disha canter like the neighbour State Chandigarh.

\section{Timing of Operation}

Timing of the provision of the service delivery, working hours and working days put a direct impact on the satisfaction level of citizens. The e-disha centre of Panchkula has been working Monday to Friday; 9:00 AM to 5:00 PM. but public dealing at the counter is available only 9:00AM to 1:00 PM. The analysis of results reveals that $68 \%$ respondents were satisfied with regard to the timing of operation of e-disha centers. Therefore $32 \%$ respondent suggested that the time of public dealing should be increased at e-disha centers and these centres must be opened at Saturday and Sunday so that citizens can get services without taking leaves from their offices.

\section{Dealing of personnel}

At the service counter personnel dealing, his ability to perform job and well-mannered behaviour play a very important role. In this study an attempt was made to collect the information regarding the above said qualities. The analysis of the information reveals that $98 \%$ respondent were satisfied with regard to the dealing of personnel at service counter. Further 99\% respondents express their satisfaction regarding the job competence of e-disha personnel.

\section{Location of Centre}

Location is also an extremely essential factor, which determines the level of satisfaction of the citizens. Location should be easily approachable, near to main road, market and bus stop. Both Panchkula and Rewari centres are located in the mini secretariat of the district which is very near to local bus stand. The analysis of the information reveals that $74 \%$ of the respondents were satisfied with the location of these centres. On the other hand $26 \%$ respondents were not satisfied with the location of these centres because these people have to travel 30-35 km to access the services of e-disha centres. Respondent have made some suggestion in this regard that government should establish the branches in the rural area as soon as possible.

\section{Basic Public Amenities}

The availability of basic facility to the citizens such as covered space; drinking water; fans; air conditioner; lighting; proper sitting space; toilet and parking etc. put a little impact to determine the level of satisfaction. An attempt was made to check the opinion of citizens regarding the availability of these facilities at e-disha centres. 78\% respondents were satisfied with these basic public amenities. Further respondent suggested that ramp facility for physical handicapped persons should be available at Rewari e-disha centre, improve parking facility and tidiness of toilets. 


\section{Simplification of procedures and Time Saving}

The introduction of e-governance has changed the traditional pattern of public service delivery. Thus, e-governance is being considered as powerful instrument, which deals with the problems confronting the governance system in the developing countries and is providing speedy, quick and low cost services to the citizens. In this an attempt was made to check the responses of respondents in this regard. 92\% respondents said that e-governance has been providing speedy delivery of services and $94 \%$ respondents believed that it has simplification of procedure of services. On the other hand e-governance has been saving time and removing harassment of visiting various departments.

\section{Transparency and Corruption}

The emergence of e-governance has changed the structure and nature of work of the administrative organizations and is helping in achieving the goals of good- governance and making the government more transparent, accountable and efficient. In this regard information collect from the respondents and $86 \%$ said that services through e-disha centres have brought transparency in the system. Further $87 \%$ respondents think that the services of e-disha centres have been reducing the level corruption.

\section{CONCLUSION AND SUGGESTIONS}

The survey and personal observation result some interesting findings. Here some recommendations have been made to strengthen the policy initiatives of the Haryana government:

- The state government shall implement the Common Services Centre Scheme through the state as soon as possible.

- Each village in Haryana should have one e-disha centre so that the citizens get services to the nearest place.

- E-disha centres should include additional services in their already exciting list of services. The suggested services are the payments of electricity bills, issue of voter cards, passport services, old age card, bus passes for students etc.

- E-disha centres should be opened all seven days from 9:00 am to 8:00pm so that citizens can get services without taking leaves from their offices.

- There should be a proper arrangement for elderly and physically handicapped citizens such as ramp facility, provision of separate service counter, clean and dry toilets and purified drinking water.

- The parking facility should be improved by keeping in mind the rainy season.

- To cope up the increasing pressure on the working staff, it is recommended that the number of employees must be increased.

\section{REFERENCES}

[1] Anil Monga, Akshat Mehta and Kuldeep Singh (2007), "E-Governance and Quality of Service: The Indian Experience", Management in Government, October-December, pp. 37-52.

[2] C.S.R. Prabhu (2004) "E-governance Concepts and Case Studies", Prentice Hall of India, New Delhi, pp.116-126.

[3] S.N sangita and Bikash Chander Dash, (2008), "The Indian Journal of Public Administtraton, Vol LIV, No.1, Janurary-March,pp.141-159

[4] Tejinder Sharma, (2002), "e-governance: Process Re-engineering Approach" The Indian Journal of Public Administtraton, Vol XLVIII, No.4, October-December. P-607.

[5] Vivek Gupta and Prashanth (2004) "The E-seva Project: Providing G2C Services in Andhra Pradesh (India)", e-government Concepts and Cases, the ICFAI University Press., Hyderabad, pp. 164-183.

[6] http://www.esuvidha.goup.in/

[7] http://www.maharashtra.gov.in

[8] www.hartron.org

[9] www.haryana.gov.in

[10] http://www.apdip.net 